\title{
Regenerating Waste to Energy: A Scenario-Based Assessment of Lagos, Nigeria
}

\author{
Adenike Opejin \\ Masters of Urban and Environmental Planning \\ School of Geographical Sciences and Urban Planning, Arizona State University \\ 975 S Myrtle Ave, Tempe, AZ 85281, United States \\ Tel: 480-845-9165Ｅ-mail: opejin.adenike@gmail.com \\ David Pijawka (Corresponding author) \\ School of Geographical Sciences and Urban Planning and \\ Julie Anne Wrigley Global Institute of Sustainability, Arizona State University \\ 975 S Myrtle Ave, Tempe, AZ 85281, United States
}

Tel: 480-540-5293 E-mail: pijawka@asu.edu

Received: August 3, 2016 Accepted: August 17, 2016

doi:10.5296/emsd.v5i2.9822 URL: http://dx.doi.org/10.5296/emsd.v5i2.9822

\begin{abstract}
This study uses scenario-based approaches to assess the regenerative capacity of transforming organic wastes into electric power for the City of Lagos, Nigeria. Lagos represents a rapidly growing city with a population of 21 million in a developing country where serious shortages are experienced in producing sufficient electric power. As in many developing countries, rapid urbanization has lead to mismanagement of solid waste disposal, illegal deposal methods, issues in landfill infrastructure, and inefficiencies in developing recycling industries and other regenerative systems. This paper examines the feasibility of regenerating organic waste into electricity by projecting the volume of methane gas that could have been harvested in two closed landfills and one still operating landfill. The analysis applies the United States Environmental Protection Agency Landfill Gas Emissions Model (U.S. EPA LandGEM) and Intergovernmental Panel on Climate Change (IPCC) models to measure waste to methane gas generation by developing data on organic waste capture, landfill physical characteristics and
\end{abstract}


factors for methane production, and the quality of waste management. Utilizing existing conversion models, the methane gas amounts are assessed in terms of potential electricity generation. The study also projected the waste-to-energy production of three new proposed landfills in Lagos from 2017 to 2050 and found that methane-produced electricity could meet the later energy demands of the city.

Keywords: Waste to energy, Regeneration, Organic waste, Carbon emissions, Energy mix

\section{Introduction}

As urbanization rates continue to increase especially in developing countries, proper waste management methods such as regenerating waste into electrical power becomes a significant sustainability objective. Pijawka (2015) has noted that developing countries with growing urbanization rates often have weak resiliency in terms of infrastructure development to manage their waste streams. In these countries' megacities, managing waste has become burdensome due to the lack of infrastructure for reuse/recycling, limited land for new landfills, and most pressing, the significant levels of illegal solid waste dumping. In some countries, illegal dumping may reach as high as $40 \%$ percent of total generated waste.

From a sustainability point of view, landfill waste disposal is the least desirable option for effective waste management as it presents negative environmental and health impacts and takes land away from urban development objectives such as public housing. In his book Regenerative Design for Sustainable Development, Lyle (1994) states that the problem of handling solid waste is associated with its definition as unwanted and worthless material to be discarded after use. Arguing that this definition leans on the assumption that energy and used materials cease to exist in a functional sense, Lyle found that, based on the laws of thermodynamics, energy continuously degrades and materials change form and state. This includes waste that when it changes from one form to another can pose environmental dangers. Therefore, it is pertinent to adopt waste management strategies that assimilate, filter, store and produce new uses to reduce the adverse impacts and enhance regenerative uses, such as energy.

Waste management has been categorized into six approaches-prevention, minimization, reuse, recycling, energy recovery, and disposal from the most to least preferred as shown in Figure 1. The most economical of the methods is waste disposal in landfills and open dumps, which is why it is the most widely used approach. However, most developed countries have established policies to encourage cities to move up the hierarchy of waste management from landfilling to prevention, the most favored option for regenerative uses and environmental benefits. Prevention suggests activities that do not result in waste materials requiring further action. For example, permaculture requires that waste materials be used as fertilizer for support of natural systems. 


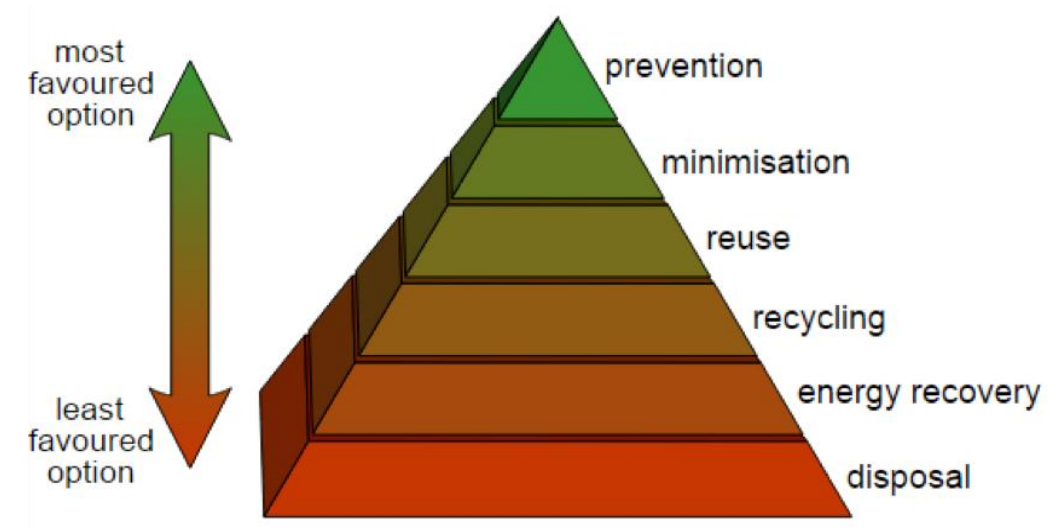

Figure 1. Waste management hierarchy. Source: www.waste-to-energy.com

Prevention is the most sustainable option but also the most difficult to achieve in developing countries with increasing population and lack of economic prosperity. However, regenerative systems for managing organic waste are gaining momentum. Hammarby Sjöstad in Stockholm, Sweden exemplifies this model through its closed-loop system where waste is integrated into the cycle to produce resources such as biogas and compost (Rutherford, 2013). As of 2013 , only $5 \%$ of the waste generated in the city went to landfills; the remainder was used to generate energy (for every one ton of waste, 3000 kilowatt hours (kWh) of energy is generated) or converted to compost used to improve the quality of soil (Rutherford, 2013). In developing countries, there is an urgent need to adopt these more regenerative waste management systems rather than the traditional end-of-pipe solutions.

This paper looks at regenerative scenarios of converting organic waste landfill gas (LFG) from existing (both active and inactive) and planned landfills into electricity then measures the impacts in Lagos, Nigeria. Lagos was chosen as the case study due to its size (21 million people) and continued growth. The goal is to demonstrate the regenerative potential of organic waste and LFG for a more sustainable systems approach to future waste management. Using a scenario-based analysis, the study answers the following questions:

1) Considering the characteristics of waste, and existing and future landfill conditions, to what extent would it be possible to capture landfill methane to generate electricity?

2) How much methane has been produced in Lagos landfills since inception to closing, what could the potential electricity generation from this methane have been if the necessary infrastructure had been in place, and can the future generation of methane be projected?

3) What are the benefits that Lagos can derive from capturing landfill methane gas for electricity generation?

4) Could these regenerative methods be implemented in other developing country cities?

The rapid urbanization of the city has led to an increase in waste generation, which requires disposal in landfills or through other means such as recycling. According to Lagos Waste Management Authority (LAWMA), almost $50 \%$ of the 12,000 tons of waste generated per 
day in Lagos is organic waste, constituting the bulk of landfilled waste in the city. Out of the $2,058,600$ tons of organic waste generated annually, only about $8 \%$ is converted into compost through local initiatives. It is important to note that out of the three current legal landfills in the city, two have less than five more years to operate, putting more pressure on the remaining landfill, which is estimated to have less than twenty more years to operate.

Adding to the urgency is the fact that these landfills are not sanitary. As a result, there are obnoxious odors emanating from uncollected methane gas as well as leachate contaminating the ground water. Methane, a greenhouse gas (GHG), is 21 times more potent than carbon dioxide $\left(\mathrm{CO}_{2}\right)$, staying in the atmosphere for a long time and contributing greatly to climate change. Thus, it has become imperative to find ways to reduce this caustic GHG from landfills. Regenerative processes are a significant sustainable solution.

\section{Background Literature}

The challenge of managing anthropogenic waste by-products is experienced in both developed and developing countries. Although the problem is more pronounced in the developing world due to lack of proper and advanced infrastructure, the ongoing debate on sustainability and climate change has exposed that waste infrastructure such as sanitary landfills are not completely problem-free. Hence, there have been initiatives to address the problems of solid waste. These programs vary from country to country, but include zero waste programs, waste-to-energy initiatives, cradle-to-cradle endeavors and others.

According to the United Nations Report on Sustainable Cities (HABITAT, 2009), one of the current global innovations for eco-efficiency is using waste products to satisfy urban energy and material resource needs. In his book Regenerative Design for Sustainable Development, Lyle makes a strong case for changing the perception of waste as 'useless' to waste as 'resources' that can be tapped by creating closed-loop management systems. This produces a cyclical system, known as a regenerative system, for products from "cradle to cradle." The regenerative model is a resource management approach that advocates for the use of conversion and assimilation disposal methods, or 'closing the loop,' and returning both materials and nutrients to beneficial uses. It is based on the premise that all materials exist in a biological nutrient cycle or a technical nutrient cycle (Bergman, 2012).

The organic waste stream is composed of biological nutrient materials that can be safely returned to the earth through regenerative methods such as landfill gas capturing, anaerobic digestion or composting. Materials that cannot be processed by biological systems are considered part of the technical nutrient cycle (plastic, synthetic materials, computers, etc.). These materials typically do not biodegrade or take too long to biodegrade but can be reused or repurposed.

\subsection{Landfill Characterization}

While several studies have been carried out on waste characterization in different cities worldwide, few studies have explored the importance of managing waste based on these characteristics. An exception is the 52-week characterization study of municipal solid waste in Gumushane, Turkey conducted by Nas and Bayram (2008) to determine the percentage of 
components, their specification weight and the chemical components that influence management techniques. Furthermore, the majority of landfill characterization studies have focused on the entire waste stream. Gomez, Meneses, Ballinas, \& Castells (2008) characterized waste generated in Chihuahua City, Mexico into organic, paper and plastic. They established a relationship between the rate and composition of the waste stream, and the socio-economic level of the residents. A recent World Bank report on Global Waste Management found that over $50 \%$ of waste in developing countries is organic (Hoornweg \& Bhada-Tata, 2012). Organic waste is typically used for soil improvement, animal raising, and biofuel. It is important to note, however, that organic waste has diverse components with different chemical characteristics that impact its potential efficiency. For instance, wood chips, agricultural waste and other plant matter can be resistant to biodegradation due to the presence of lignin, cellulose and hemicellulose (Volger, 2014).

\subsection{Landfill Methane to Electricity}

Capturing and reusing landfill methane is a sustainable and environmentally friendly option for managing waste. This is especially true in developing countries where this can greatly benefit their energy mix and power supply. It is also one of the most economical and socially accepted methods with minimal environment consequences. Most of the studies done on LFGs to date have been geared towards methane as a contributor to climate change (Lou \& Nair, 2009). Some focus on the efficiency rate of capturing landfill gases (LGFs) compared to using an anaerobic digestion reactor (Themelis \& Uloa, 2007) or determine total methane balance and oxidation rates (Spokes et al., 2006). Our study focuses on quantifying the benefits in energy resources that can be accrued from landfill methane for Lagos.

\section{Case Study}

In a recent interview, the former Nigerian Minister for Power, Chinedu Nebo, stated that Lagos could benefit from the enormous amount of organic waste generated daily (Business, 2015). The city sits on a water-locked landmass of approximately $1533 \mathrm{~km}^{2}$, which limits physical development. Located on the Gulf of Guinea in the Atlantic Ocean, it is built on several low-lying islands, tropical marshes, reclaimed lands, and a coastal mainland area that sprawls out into the neighboring state of Ogun. Its climate is that of a tropical rainforest and it sits below sea level, placing it at considerable risk for coastal flooding (Encyclopedia Britannica, 2015; Filani, 2012).

This megacity is the most populous city in Nigeria. It has great diversity in terms of population, income, education and ethnicity. With over 250 ethnic groups, the city receives people from every part of Nigeria and beyond. In its present form, Lagos' overflowing urban agglomeration area of $907 \mathrm{~km}^{2}$ holds a UN-estimated population of 13 million people (Demographia World Urban Areas, 2015) while its metro footprint extends $1533 \mathrm{~km}^{2}$ (Filani, 2012) and includes over 21 million residents (Lagos Bureau of Statistics, 2015). It is the economic hub of Nigeria, generating over $25 \%$ of the country's total gross domestic product.

The volume of solid waste generation in Lagos increases every day with the influx of people, adding to an already congested city. The current population generates over 12,000 metric tons 
of waste per day, of which only about 50\% makes it to landfills (LAWMA, 2014). According to LAWMA's 2014 report, $45 \%$ of waste generated in the city is organic, followed by plastic $(15 \%)$, paper $(10 \%)$, putrescibles or decomposables $(8 \%)$, glass $(5 \%)$ and textiles $(4 \%)$. There is absolutely no doubt that Lagos will face more problems in the near future if a more sustainable approach to waste management is not found. This is especially true if the population actually reaches forty million people by 2050 as forecasted by United Nations (UN Dept of Economic and Social Affairs, 2015).

While the population of the city is increasing at an estimated annual rate of at least $3.6 \%$, the municipal authority in charge of waste is collecting an average of $10 \%$ less refuse per capita every year (Onibokun, Adedipe, \& Sridlier, 2000). A major cause of this is the city's vast informal settlements. With over $66 \%$ of the population living in these settlements, environmental management such as sanitation and solid waste has been a formidable task for the government.

Waste from these settlements is dumped indiscriminately in places such as rivers, canals, drainages or burned on illegal dumpsites or even in residents' backyards. Waste collected under the private sector partnership (PSP) is disposed of in the three legal landfills-Olushosun, Solus and Abule-Egba. However, there is growing concern over the environmental problems caused by the landfills as the city has developed rapidly in the areas where the landfills are located, thereby causing nuisance to residents living around this area. The incessant seasonal flooding experienced in most parts of the city exacerbates this. Fortunately, this flooding has started to increase the awareness of the need for better and safer disposal methods. To become more environmentally sustainable, managing organic waste is essential. This is especially true for Lagos with its projected population increase and the high costs of siting and operating new landfills.

\section{Methodology}

The volume of feasible landfill biofuel is dependent on conditions (temperature, soils, gas run-off, etc.) as well as the composition of materials. Using a multi-methods approach, a baseline composition study on organic waste streams in Lagos was performed and projections for the three proposed new landfills were made. The organic waste share of total waste and landfill quality factors were also estimated. This is important not only for revealing the potential benefits that could be tapped, but also in helping select technologies to yield optimal results. Data was collected from fieldwork, historical waste data, government reports and interviews.

The organic components of Lagos' Municipal Solid Waste (MSW) account for around 45\% of the total waste generated on a daily basis (LAWMA, 2010). Based on parameters from the literature, the amount of methane gas expected to be generated in each landfill from inception to end of life was calculated using the United States Environmental Protection Agency Landfill Gas Emissions Model (US EPA LandGEM) software (Pipatti et al., 2006). The results were then used to evaluate how much electricity each year could be generated from the methane gas at the existing and proposed facilities. We used the annual baseline population growth rate of $3.19 \%$ estimated and multiplied it by the $0.65 \mathrm{~kg}$ per capita of waste 
generation (LAWMA, 2010) for our projected estimations.

Projections were also made on the overall benefits to Lagos in terms of electricity generation that would be produced over the next 20 years based on population estimates for each year. Abraxas Energy Consulting's Energy Conversion Calculator was used to estimate how much electricity could be generated from the methane gas produced in each of Lagos' existing and proposed landfills every year. This enabled the calculation of methane gas in cubic meters to be converted to electricity in megawatts (MW). Abraxas Energy Consulting's Energy Conversion Calculator is not the only energy calculator available for conversion, but it is the most popular among organizations that are running energy accounting. More so, it was used in the first Landfill Gas to Energy study conducted in Nigeria in 2010 (CPE, 2010).

In Lagos, a large portion of household and commercial waste generated is deposited in landfills across the city. The organic components of Municipal Solid Waste (MSW) account for an estimated $45 \%$ of the total waste generated on a daily basis (LAWMA, 2010). Decomposition transforms the organic waste to LFG composed of 50\% methane gas. Presently, Lagos does not have LFG collection systems in any of its landfills. Therefore, the biogas is released into the atmosphere losing its potential for regenerative purposes. This presents not only a lost opportunity for resource efficiency but also contributes to global GHG emissions and climate change.

The Centre for People and Environment (CPE) conducted the only known LFG study conducted so far in Nigeria in 2010. The study explored the feasibility of producing landfill gas in Nigeria based on three landfills in different regions of the country. It was sponsored by the US EPA and used their LandGEM software Version 3.02 published in 2005.

For Lagos, the only study carried out on LFGs was done by Ably Carbon \& Bionersis (2006). The study essentially assessed the suitability of capturing landfill gases for the Abule Egba, Solous and Olushosun landfills and specifically related to the possibility of earning carbon credits through the Clean Development Mechanism (CDM) established under the 1997 Kyoto Protocol. It analyzed factors such as soil conditions, temperature, and chemicals that together would conclude if methane gas could be captured at landfill sites and if yes, how much. Using the LandGEM model, this study also evaluated landfill conditions and factors that would contribute to the amount of methane gas generated. The factors included the use of two small landfills for producing methane. The data breaks down quantitatively into the amounts of methane and subsequently, how much electricity could be generated now and in the future, if the necessary infrastructure was in place.

Our analysis chose the LandGEM model as it was used in previous studies to analyze landfill methane in the three proposed landfills and it has been used widely in the United States and internationally (Global Methane Initiative, 2012). LandGEM is an automated estimation tool with a Microsoft Excel interface that can be used to estimate emission rates for total landfill gas, methane, carbon dioxide, non-methane organic compounds, and individual air pollutants from municipal solid waste landfills. The accuracy and reliability of the results generated using this model depends largely on a number of input data. The model (below) uses the first-order decomposition rate equation to estimate annual emissions of methane over a time 


\section{Macrothink

period that is being defined by the user.

$$
Q C H_{4}=\sum_{i=1}^{n} k L_{0} \sum_{j=0.1}^{1} k L_{0}\left[\frac{M_{i}}{10}\right] e
$$

Where

QCH4 = annual methane generation in the year of the calculation (m3/year)

$\mathrm{i}=1$-year time increment

$\mathrm{n}=($ year of the calculation $)-($ initial year of waste acceptance $)$

$\mathrm{j}=0.1$-year time increment

$\mathrm{k}=$ methane generation rate (year-1)

$\mathrm{Lo}=$ potential methane generation capacity $(\mathrm{m} 3 / \mathrm{Mg})$

$\mathrm{Mi}=$ mass of waste accepted in the ith year $(\mathrm{Mg})$

tij $=$ age of the jth section of waste mass Mi accepted in the ith year (decimal years, e.g., 3.2 years)

$\mathrm{e}=$ natural exponential scientific function used for continual decay

Note that the value of $\mathrm{k}$ is primarily a function of several factors such as moisture content of the waste mass, availability of the nutrients for microorganisms that break down the waste to form methane and carbon dioxide, $\mathrm{pH}$ of the waste mass, and temperature of the waste mass. The $\mathrm{k}$ value for Lagos landfills was obtained from the IPCC default values for developing countries and based on the number of urban inhabitants multiplied by the MSW disposal rate.

\section{Results: Assessing the Waste to Energy Option for Lagos}

\subsection{Olushosun Landfill Analysis}

This landfill accepted about $40 \%$ of the total waste generated in Lagos (LAWMA, 2012). Some parts of the landfill were closed in 2007 due to attainment of the $12 \mathrm{~m}$ desired height above the surface for the landfill as planned by the Waste Management Agency. New cells were opened up to receive waste starting from 2008, and the entire landfill is proposed to be closed by 2017 (Ably Carbon \& Bionersis, 2012). 
Table 1. Waste deposited in the Olushosun Landfill

\begin{tabular}{|c|c|c|}
\hline Year & Waste Deposited (Metric Tons) & Cumulative Metric Tons \\
\hline 1992 & $165,909.09$ & $165,909.09$ \\
\hline 1993 & $174,204.55$ & $340,113.64$ \\
\hline 1994 & $182,914.55$ & $523,028.19$ \\
\hline 1995 & $192,060.91$ & $715,089.10$ \\
\hline 1996 & $201,663.64$ & $916,752.74$ \\
\hline 1997 & $211,746.36$ & $1,128,499.10$ \\
\hline 1998 & $222,333.64$ & $1,350,832.74$ \\
\hline 1999 & $233,450.91$ & $1,584,283.65$ \\
\hline 2000 & $245,123.64$ & $1,829,407.29$ \\
\hline 2001 & $257,379.09$ & $2,086,786.38$ \\
\hline 2002 & $270,248.18$ & $2,357,034.56$ \\
\hline 2003 & $283,760.91$ & $2,640,795.47$ \\
\hline 2004 & $297,949.09$ & $2,938,744.56$ \\
\hline 2005 & $312,846.36$ & $3,251,590.92$ \\
\hline 2006 & $328,489.09$ & $3,580,080.01$ \\
\hline 2007 & $344,912.73$ & $3,924,992.74$ \\
\hline 2008 & $567,814.55$ & $4,492,807.29$ \\
\hline 2009 & $596,205.45$ & $5,089,012.74$ \\
\hline 2010 & $626,015.45$ & $5,715,028.19$ \\
\hline 2011 & $657,316.36$ & $6,372,344.55$ \\
\hline 2012 & $690,181.82$ & $7,062,526.37$ \\
\hline 2013 & $724,690.91$ & $7,787,217.28$ \\
\hline 2014 & $760,925.45$ & $8,548,142.73$ \\
\hline 2015 & $798,971.82$ & $10,186,034.55$ \\
\hline 2016 & $838,920.00$ & $11,066,900.91$ \\
\hline 2017 & $880,866.36$ & \\
\hline & & \\
\hline & & \\
\hline
\end{tabular}

The historical amount of waste dumped in Olushosun landfill per metric ton from 1992 until 2017 is shown in Table 1.

In the study scenario, methane production was estimated from the year the landfill started operation in 1992 to 2020. Even though the landfill is expected to close in 2017, methane production was estimated until 2020 in the scenario, as the landfill will continue to generate methane for at least three years after closure. The scenario is based on landfill characteristics incorporated into the model but also assumes annual waste deposits over the entire time period and annual methane generation. The scenario assumes the volume of methane that could have been produced. 


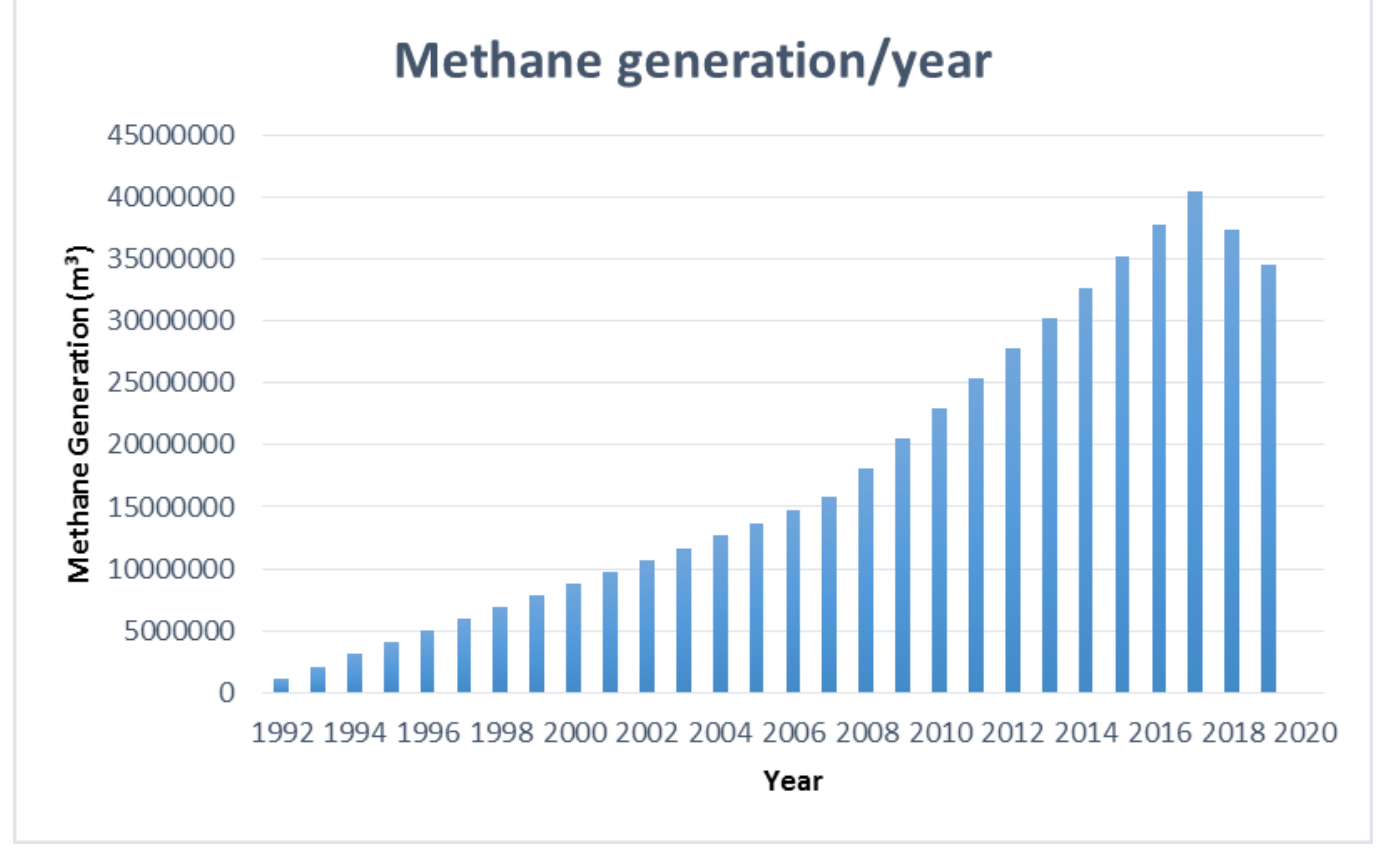

Figure 2. Olushosun Landfill Methane Generation ( $\left.\mathrm{m}^{3} / \mathrm{year}\right)$

The summary of methane recovery projections for the Olushosun landfill is illustrated in Figure 2. (See Appendix 1 for the complete estimation of methane and electricity generation at the Olushosun landfill.)

In the first year, methane production is zero. This is because it takes time for decomposition of organic waste to begin producing methane. Beginning in 1993, production steadily increases until 2018, a year after the landfill is scheduled to close. After 2018, methane production begins to decrease. This implies that capturing methane in this landfill requires quick action for a viable return on investment. The total accumulated methane over time is estimated at about 496,787,641 cubic meters. If full capture of this methane had taken place, approximately 5,244,440 megawatts of electricity would have been generated. Unfortunately, since no capturing has taken place to date, a significant amount of this gas has been lost to the atmosphere and it is impossible to determine the remaining quantity without further research. This scenario tells us how much electricity could have been generated if the capturing infrastructure and equipment for generating electricity was in place.

\subsection{Abule Egba Landfill Analysis}

A total of 2,628,726 metric tons of waste was deposited in the Abule-Egba landfill as of its closing in 2009 (e.g., Table 2). The waste tonnage data in this landfill may not be accurate due to the absence of a weighbridge during operations; however, the study assumed that the waste data used in the Ably Carbon \& Bionersis report is correct, as it was provided by the LAWMA. 


\section{Macrothink \\ Environmental Management and Sustainable Development \\ ISSN 2164-7682 2016, Vol. 5, No. 2}

Table 2. Waste Tonnage of Abule- Egba Landfill

\begin{tabular}{|c|c|c|}
\hline Year & Waste Deposited (Metric Tons) & Cumulative Metric Tons \\
\hline 1995 & 70,000 & 70,000 \\
\hline 1996 & 74,200 & 144,200 \\
\hline 1997 & 78,652 & 222,852 \\
\hline 1998 & 83,371 & 306,223 \\
\hline 1999 & 88,373 & 394,597 \\
\hline 2000 & 93,676 & 488,272 \\
\hline 2001 & 99,296 & 587,569 \\
\hline 2002 & 105,254 & 692,823 \\
\hline 2003 & 111,569 & 804,392 \\
\hline 2004 & 111,569 & 915,961 \\
\hline 2005 & 167,354 & $1,083,316$ \\
\hline 2006 & 251,031 & $1,334,316$ \\
\hline 2007 & 375,547 & $1,710,893$ \\
\hline 2008 & 564,820 & $2,275,713$ \\
\hline 2009 & 353,012 & $2,628,726$ \\
\hline
\end{tabular}

Source: LAWMA, 2012

The landfill has an average height of 11 meters above the surface and is considered 'unmanaged.' It served low-income neighborhoods in the Alimosho Local Government Area (LGA), the largest LGA in Lagos. The amount of landfill methane gas was calculated for each year of operation using LandGEM software. For each year in which waste was deposited from inception to closing and a projection to the year 2020 was completed, an assumed cap year for the three landfills in question for the sake of this research. A total of $149,105,317.6 \mathrm{~m}^{3}$ (cubic meter) of methane would have been produced. If capturing methane commenced at the start of the landfill, a total of 1,574,060.74 MW of electricity could have been generated. As stated earlier, capturing methane and generating electricity is contingent on the type of equipment used and the time operations begin. 


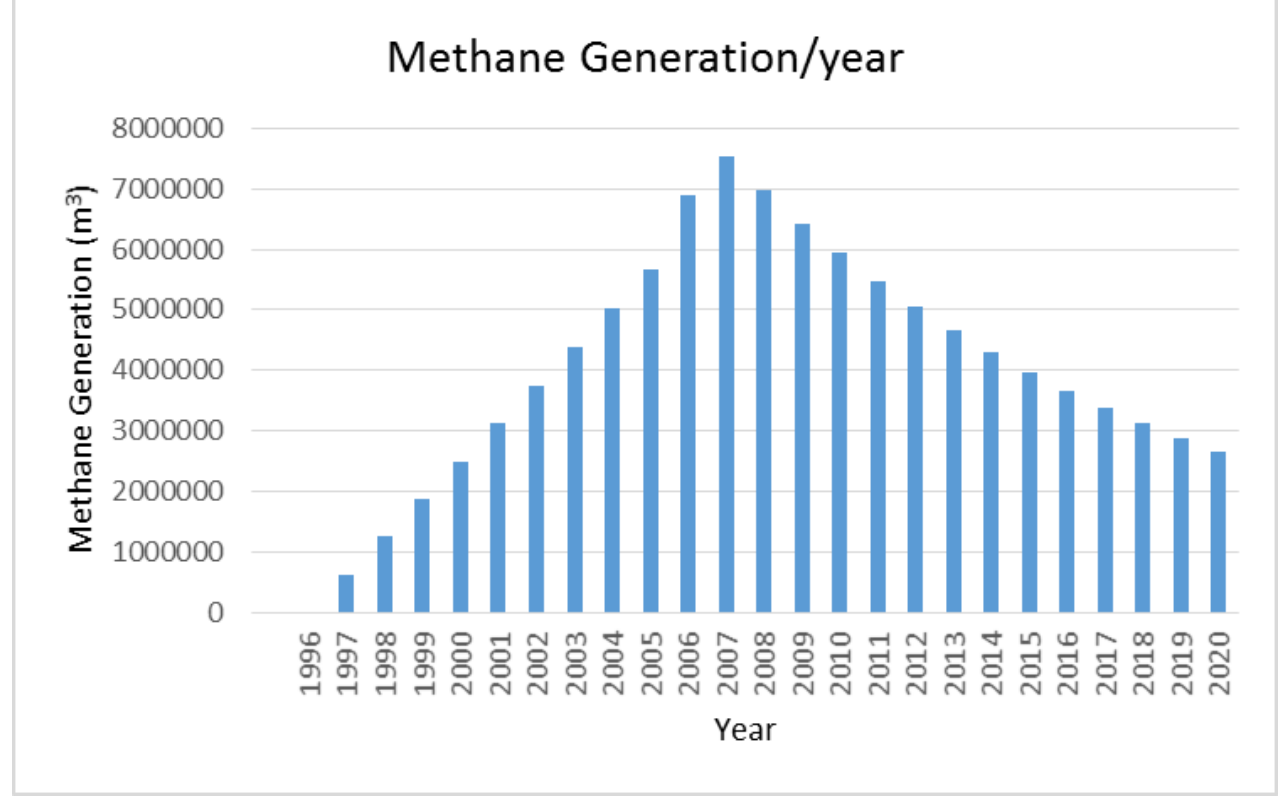

Figure 3. Graph of methane gas generation in Abule-Egba Landfill

The summary of methane recovery projections for the Abule-Egba landfill is illustrated in Figure 3. (See Appendix 2 for the complete estimation of methane and electricity generation at the Abule-Egba landfill.)

\section{Solous 1 Landfill Analysis}

The Solous landfill is divided into three parts called Solous I, Solous II and Solous III. Solous II and Solous III were ruled out of the possibility of capturing LFGs due to unfavorable landfill conditions (Ably Carbon \& Bionersis, 2012). Again, waste deposit tonnage data in this landfill may not be accurate due the unavailability of a weighbridge, but the data from LAWMA was used and is deemed reliable.

Table 3. Waste deposited in Solous I landfill

\begin{tabular}{|l|l|l|}
\hline Year & Metric Tons Disposed & Cumulative Metric Tons \\
\hline 1996 & 100,122 & 100,122 \\
\hline 1997 & 106,512 & 206,634 \\
\hline 1998 & 113,311 & 319,945 \\
\hline 1999 & 120,544 & 440,489 \\
\hline 2000 & 128,238 & 440,489 \\
\hline 2001 & 136,423 & 705,150 \\
\hline 2002 & 145,131 & 850,282 \\
\hline 2003 & 154,395 & $1,004,677$ \\
\hline 2004 & 164,250 & $1,168,927$ \\
\hline 2005 & 264,375 & $1,415,302$ \\
\hline 2006 & 184,781 & $1,600,083$ \\
\hline
\end{tabular}




\section{Mll Macrothink}

Solous I has the least methane generation capability of the three landfills studied due to its relatively small size, period of waste deposition up to 2006 and quantity of organic waste deposited. Waste was only deposited at this landfill for a period of 10 years. The total quantity of methane estimated to have been generated from 1996 to 2006 when the landfill closed and projected out for fourteen years more years to 2020 for scenario purposes is $101,198,084.1 \mathrm{~m}^{3}$. From this estimate, the potential energy generation was about 1068318.3 MW.

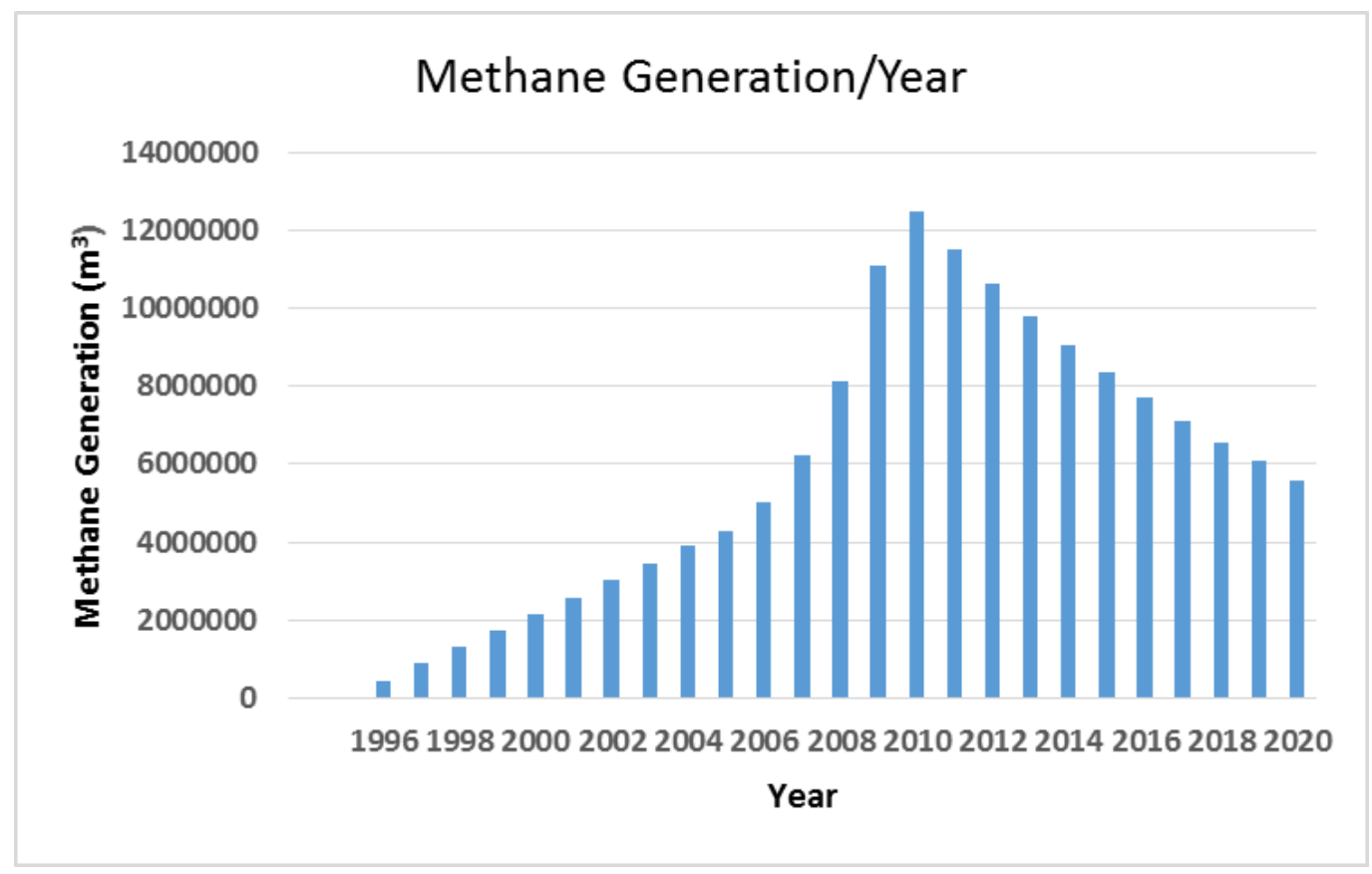

Figure 4. Graph of methane in Solous I Landfill $\left(\mathrm{m}^{3} / \mathrm{year}\right)$

The summary of methane recovery projections for the Solous I Landfill is illustrated in Figure 4. (See Appendix 3 for the complete estimation of methane and electricity generation at the Solus I landfill.)

\section{Projection of Future Methane and Electricity Generation Capacity of Three Proposed Landfills}

Our analysis shows that Lagos had the capacity to generate a significant amount of electricity from landfill gas in the past. Unfortunately, electricity generation infrastructure was not in place. However, all hope is not lost as there is still a considerable amount of methane gas present in the three existing landfills. To avoid further waste of landfill resources, this study also estimates how much methane and electricity Lagos can produce from future waste that will be disposed of in three new proposed landfills.

The analysis projected the population and waste generation in the city to the year 2050 . According to the Lagos Bureau of Statistics data, Lagos had a population of 23,305,971 in 2015. Using this as the baseline year with an annual estimated growth rate of $3.19 \%$, a population figure was estimated for each year up to 2050. Using the daily per/capita waste generation rate of $0.65 \mathrm{~kg}$ in the city (LAWMA, 2012), an estimated projection of waste 


\section{Macrothink}

Environmental Management and Sustainable Development

ISSN 2164-7682

2016, Vol. 5, No. 2

tonnage from 2015 to 2050 was also calculated. We anticipate that only $75 \%$ of the total waste generated each year will make it to landfills due to the city's history of indiscriminate and illegal dumping and the assumption that this practice will continue. In addition, we used the current rate of $45 \%$ of total waste generated as organic waste. Finally, we assumed in our model that the new landfills will be sanitary and well managed. These data assumptions facilitated the estimation of how much methane gas could be recovered from the estimated landfilled waste and how much electricity could then be generated from it over the scenario-based timeline.

Based on our estimates, the total methane that would be generated in Lagos from 2015 to 2050 from the three proposed landfills is $32,181,832,493 \mathrm{~m}^{3}$. This could lead to a significant source of electrical energy for the city, as an estimated 339,051,195 megawatt hours (MWh) would be produced over time. The question then arises as to what percentage of the city's energy needs would be met with this electricity. Siemens' Green City Index report (Siemens, 2010) estimates the total electricity used by Lagos residents at $222 \mathrm{KWh}$ per capita. In order to calculate the annual electricity needed for each projection year, the estimated population was multiplied by the per capita electricity in $\mathrm{kWh}$ to get an estimate of the city's energy demand for that year. The total cumulative energy demand from 2015 to 2050 is estimated at 340,811,241.8 MWh. Thus, the amount of electricity that could be generated from landfill methane would meet then surpass the electricity demands of Lagos' residents (see figure 5). Appendix 4 provides the detailed projections of waste, methane, future electricity, and electricity needs from 2015-2050.

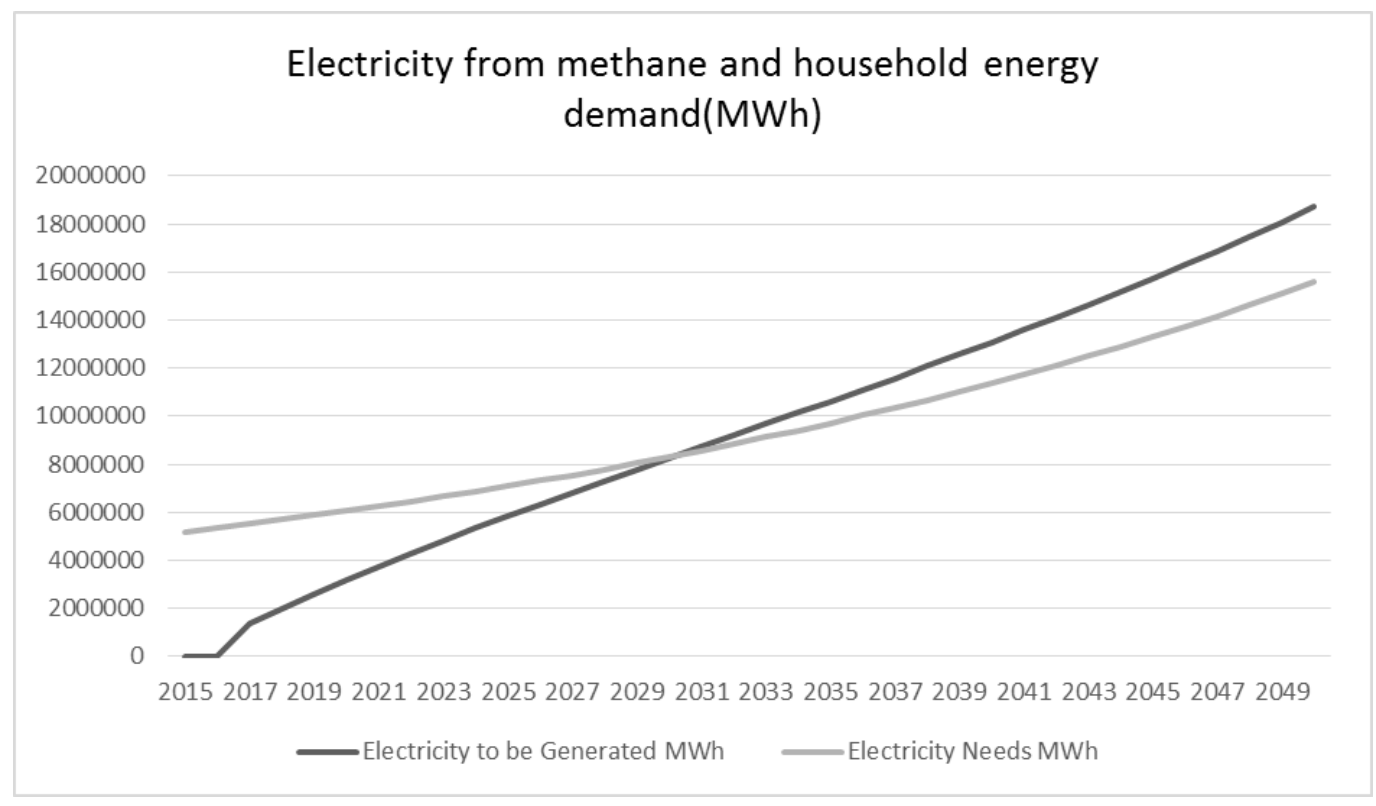

Figure 5. Annual electricity from methane and energy demand for Lagos in MWh.

The city currently gets its energy from hydro and thermal power sources that have failed to meet demand for several decades. Our study shows that investing in landfill methane capturing would add to the energy mix, strengthening the supply and meeting the city's electricity needs for years to come. Specifically, our projections indicate that regenerative 
waste-to-energy systems for landfill waste will have the capacity to meet all of Lagos' energy needs by around 2030. Until that time, a mixed fuel supply will continue to be required. It is worth noting that for the city to be able to harness this potential energy, there is a need for significant investment in green infrastructure to capture, transform and transmit the electricity.

\section{Conclusions and Implications}

Findings from this study show that there are significant opportunities for developing country megacities to meet their electricity demands by implementing sustainable practices and green infrastructure, particularly converting waste to energy through landfill methane capture. It is important to note that our analysis is scenario based; that is, we developed the analysis to determine the amount of methane that could have been generated from landfill waste and how much electricity could be generated from this methane from 1997 to 2050 if the infrastructure was in place. Because capturing equipment is not presently on these landfills, it is hard to ascertain how much gas is left that can be captured for electricity production. However, if action is taken sooner rather than later, a considerable amount of this gas could potentially still be captured from both closed and operating landfills.

Results estimated that Olushosun, the biggest and only currently operating landfill in Lagos, Nigeria, could generate around 497 million cubic meters $\left(\mathrm{m}^{3}\right)$ of methane gas from landfilled waste deposits from 1997 to the end of 2020 with the potential for generating over 5.2 million MWh of electricity over the 23 years period. Similar results were found for Lagos' other landfills, Abule-Egba and Solous 1, where an average of 149 million $\mathrm{m}^{3}$ and 101 million $\mathrm{m}^{3}$ methane gas could be generated cumulatively with the potential for producing 1.6 million MWh and 1.1 million MWh of electricity, respectively. Of particular importance is the estimate that Lagos has the potential to recover significant amounts of methane well into the future.

Lagos has plans to build three new landfills. These facilities present an opportunity to incorporate the green infrastructure and technology necessary to capture the methane for electricity production. Our models estimate that there is the possibility of recovering a total of 32.2 billon $\mathrm{m}^{3}$ of methane from 2015 to 2050 , which could be used to produce 339 million MWh of electricity. Cumulatively, we estimate that Lagos' total energy demand from 2015 to 2050 is slightly over 340 million MW. This is based on the $222 \mathrm{KWh}$ per capita estimate obtained from Siemens' Green City Index report of 2010.

For decades, electricity generated in the city from hydro and thermal power has fallen short of demand resulting in incessant power outages, putting the city in darkness and forcing people to use liquefied gas generators. Adding the estimated annual average of 9.6 million MWh electricity produced from landfill methane gas to the country's energy mix would resolve this problem, even if the city were to reach its projected population growth of forty million people by 2050. Of course, it could be argued that to achieve this level of electricity generation, large infrastructure investments are needed to install equipment. The possibility of registering the construction and operation of the three new landfills as CDM-compliant facilities will enable Lagos to get supporting funds from carbon credits. 


\section{Macrothink}

Waste management best practices in developed countries are leaning towards zero waste and diversion of organic waste from landfills to combat climate change and extend the lifespan of landfills. The diverted organic waste is sent to compost facilities or used to produce heat and electricity using Anaerobic Digestion (AD). A key factor that makes this possible is that organic waste is sorted at the source. This is a big challenge in developing countries' cities such as Nigeria, as wastes are comingled and never sorted before disposal. Thus, the diversion of organic waste in Lagos is not currently feasible. However, converting landfill methane to electricity is a viable waste management option for the city given its significant amount of organic waste. We speculate that this may be a feasible option for megacities in other developing countries as well as it adds to the energy mix of the city, enabling a more stable power supply to meet growing demand.

\section{Acknowledgement}

Funding for this research came from the School of Geographical Sciences and Urban Planning, Arizona State University; the Resource Innovation and Solutions Network (RISN) Partnership between Arizona State University and Nigeria; and the Walton Sustainability Solutions Initiative, Julie Ann Wrigley Global Institute of Sustainability, Arizona State University.

\section{References}

Ably Carbon, \& Bionersis. (2012). Feasibility analysis of landfill gas opportunity at municipal landfills in Lagos, Nigeria. A report submitted to the Lagos State Waste Management Authority. Retrieved from https://www.globalmethane.org/expo-docs/posters/MSW/MSW_NI_Project_Lagos-LFG_FIN AL.pdf.

Bergman, D. (2012). Sustainable design: a critical guide. Princeton Architectural Press. Retrieved from http://site.ebrary.com/lib/alltitles/docDetail.action?docID=10553292.

Business Year, The. (2015). Big Operation: Interview with the Nigeria Minister of Power, $\begin{array}{lllll}\text { Professor } & \text { Chinedu } & \text { Nebo. } & \text { Retrieved }\end{array}$ https://www.thebusinessyear.com/nigeria-2015/big-operation/interview.

Center for People and Environment (CPE) (2010). Landfill Recovery and Use in Nigeria (Pre-feasibility studies of using LFGE). Methane to Energy Program, US EPA, Washington DC. $\quad$ Retrieved from https://www.globalmethane.org/Data/347_Landfill.Recovery.and.Use.in.Nigeria(LFGE)Final. Report.pdf.

Demographia World Urban Areas (2015). WORLD MEGACITIES: Urban Areas with More than 10,000,000 Population 2015. Retrieved from http://www.demographia.com/db-megacity.pdf.

Filani, M. (2012). The Changing Face of Lagos: From Vision to Reform and Transformation. Cities Alliance. Retrieved from http://www.citiesalliance.org/sites/citiesalliance.org/files/Lagos-reform-report-lowres.pdf. 
Global Methane Initiative (2012). Retrieved from http://www.globalmethane.org

Gomez G., Meneses M., Ballinas L., \& Castells F. (2008). Characterization of urban solid waste in Chihuahua, Mexico. Waste Management 28(12), 2465-2471. http://dx.doi.org/10.1016/j.wasman.2007.10.023

HABITAT, U. N. (2009). Global Report on Human Settlements: Planning sustainable cities. London: Earthscan. http://dx.doi.org/10.1111/j.1745-5871.2010.00677.x

Hoornweg, D., \& Bhada-Tata, P. (2012). What a waste: a global review of solid waste management. Urban development series knowledge papers, 15, 1-98. Permanent URL: http://go.worldbank.org/BCQEP0TMO0.

Lagos State Bureau of Statistics (2015). Statistical Year Book. Retrieved from http://lagosbudget.org/pdffiles/584901_HH2013\%20PRINTERS\%20COPY\%20CORRECTE D\%20final.pdf

Lagos State Waste Management Authority (LAWMA) (2014). Solid Waste Data in the city of Lagos. Department of Planning Research and Statistics. Retrieved from http://www.lawma.gov.ng/md\%20presentation/2013/SWM\%20in\%20Lagos\%20Journey\%20 So\%20Far.pdf.

LAWMA. (2010.). Activities of the Lagos Waste Management Authority (LAWMA) for year 2010-2015. Lagos, Nigeria. Retrieved from

http://www.lawma.gov.ng/lawma_download.html.

Lagos Nigeria. (n.d.). In Encyclopedia Britannica online. Retrieved from https://www.britannica.com/place/Lagos-Nigeria.

Lou, X. F., \& Nair J. (2009). The impact of landfilling and composting on greenhouse gas

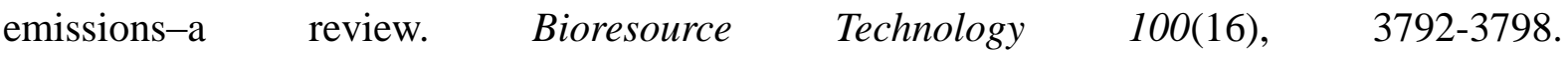
http://dx.doi.org/10.1016/j.biortech.2008.12.006

Lyle, J. T. (1996). Regenerative Design for Sustainable Development. John Wiley and Sons.

Nas, S. S., \& Bayram, A. (2008). Municipal solid waste characteristics and management in Gumushane, Turkey. Waste Management, 28(12), 2435-2442. http://dx.doi.org/10.1016/j.wasman.2007.09.039

Onibokun, A. G., Adedipe, N. O. \& Sridlier, M. K. C. (2000). Affordable technology and strategies for waste management in Africa: lessons and experience (Vol. 13). Center for African Settlement Studies and Development.

Pijawka, D. K. (2015). Sustainability for the $21^{\text {st }}$ Century: Pathways, Programs, and Policies. Kendall Hunt Publishing; $1{ }^{\text {st }}$ Edition.

Pipatti, R., Svardal, P., Silva Alves, J. W., Gao, Q., Lopez Cabrera, C., Mareckova, K. ... Yamada, M. (2006). Solid Waste Disposal. In 2006 IPCC Guidelines for National Greenhouse Gas Inventories. 5th ed. Switzerland: IPCC. 3.6-3.40. Retrieved from http://www.ipcc-nggip.iges.or.jp/public/2006gl/pdf/5_Volume5/V5_3_Ch3_SWDS.pdf 


\section{Macrothink}

Environmental Management and Sustainable Development

ISSN 2164-7682

2016, Vol. 5, No. 2

Rutherford, J. (2013). Hammarby Sjöstad and the rebundling of infrastructure systems in Stockholm. A paper presented at Chaire Ville Seminar. http://www.enpc.fr/sites/default/files/files/Rutherford\%20Hammarby\%20Sj\%C3\%B6stad\%2 0121213.pdf

Siemens (2010). African Green City Index: Assessing the environmental performance of Africa's major cities. Economist Intelligence Unit. Retrieved from http://www.siemens.co.za/sustainable-development/pdf/African-Green-City-Index.pdf.

Spokes, K., Bogner, J., Chanton, J. P., Morcet, M., Aran, C., Graff, C., ... \& Hebe J. (2006). Methane mass balance at three landfill sites: what is the efficiency of capture by gas collection system? Waste Management, 26(5), 516-525. http://dx.doi.org/10.1016/j.wasman.2005.07.021

Themelis, N. J, \& Ulloa P. A., (2007). Methane generation in landfills. Renewable Energy 32(7), 1243-1257. http://dx.doi.org/10.1016/j.renene.2006.04.020

United Nations Department of Economic and Social Affairs, Population Division. (2015). World Population Prospects: The 2015 Revision - Key Findings and Advance Tables. Retrieved from https://esa.un.org/unpd/wpp/publications/files/key_findings_wpp_2015.pdf.

US Environmental Protection Agency (US EPA) (2012). Climate Change: An overview of Greenhouse Gases. U.S. Environmental Protection Agency, Washington, DC, USA. Retrieved from https://www3.epa.gov/climatechange.

Volger, T. (2014). The Global Dialogue on Waste 2014: Drivers and barriers to waste Management in India and Nigeria. Retrieved from http://wastewise.be/2014/06/drivers-and-barriers-to-waste-management-in-india-and-nigeria/ \#.V5p_VrgrLIU.

\section{Glossary}

Anaerobic digestion - the use of microorganisms to decompose organic materials in a landfill to produce biogas.

Biofuel - Fuel derived from living matter.

Biogas - Landfill gas that is used as fuel.

First-order decomposition rate - decomposition that proceeds at a linear rate dependent upon the concentration of a single reactant. In this case study that reactant is methane.

Landfill gas (LFG) - a byproduct of decomposing landfilled organic materials. It consists of roughly $50 \%$ methane $\left(\mathrm{CH}_{4}\right), 50 \%$ carbon dioxide $\left(\mathrm{CO}_{2}\right)$ and traces of other organic compounds.

Regeneration - the use of heat (i.e., from landfilled organic material decomposition) or other components that would ordinarily be lost to produce a product (i.e., energy).

Sustainable systems approach - the integration of production, processing, distribution, 
consumption and waste management in order to enhance the environmental, economic and social health of a particular place.

\section{Appendix}

Appendix 1. Estimated Methane and Electricity generation at Olushosun landfill

\begin{tabular}{|c|c|c|c|c|c|}
\hline Year & Waste Accepted & Waste-In-Place & \multicolumn{2}{|c|}{ Methane } & Electricity \\
\hline & $M g$ & $M g$ & $M g$ & $m^{3}$ & MWh \\
\hline 1992 & 165909.09 & 0 & 0 & 0 & 0 \\
\hline 1993 & 174204.55 & 165909.09 & 700.61 & 1050156.61 & 11086.19 \\
\hline 1994 & 182914.55 & 340113.64 & 1382.39 & 2072081.17 & 21874.35 \\
\hline 1995 & 192060.91 & 523028.18 & 2048.52 & 3070568.22 & 32415.08 \\
\hline 1996 & 201663.64 & 715089.09 & 2702.07 & 4050181.78 & 42756.57 \\
\hline 1997 & 211746.36 & 916752.73 & 3345.92 & 5015261.55 & 52944.63 \\
\hline 1998 & 222333.64 & 1128499.1 & 3982.85 & 5969963.22 & 63023.14 \\
\hline 1999 & 233450.91 & 1350832.7 & 4615.52 & 6918278.31 & 73034.22 \\
\hline 2000 & 245123.64 & 1584283.6 & 5246.49 & 7864052.60 & 83018.48 \\
\hline 2001 & 257379.09 & 1829407.3 & 5878.24 & 8810997.30 & 93015.09 \\
\hline 2002 & 270248.18 & 2086786.4 & 6513.18 & 9762710.91 & 103062.05 \\
\hline 2003 & 283760.91 & 2357034.5 & 7153.64 & 10722710.93 & 113196.49 \\
\hline 2004 & 297949.09 & 2640795.5 & 7801.92 & 11694434.30 & 123454.68 \\
\hline 2005 & 312846.36 & 2938744.5 & 8460.28 & 12681255.12 & 133872.26 \\
\hline 2006 & 328489.09 & 3251590.9 & 9130.93 & 13686500.98 & 144484.34 \\
\hline 2007 & 344912.73 & 3580080 & 9816.07 & 14713473.81 & 155325.79 \\
\hline 2008 & 567814.55 & 3924992.7 & 10517.89 & 15765446.09 & 166431.15 \\
\hline 2009 & 596205.45 & 4492807.3 & 12107.04 & 18147443.00 & 191577.19 \\
\hline 2010 & 626015.45 & 5089012.7 & 13693.89 & 20526009.54 & 216687.01 \\
\hline 2011 & 657316.36 & 5715028.2 & 15284.63 & 22910391.88 & 241858.23 \\
\hline 2012 & 690181.82 & 6372344.5 & 16885.25 & 25309579.90 & 267185.75 \\
\hline 2013 & 724690.91 & 7062526.4 & 18501.58 & 27732338.41 & 292762.09 \\
\hline 2014 & 760925.45 & 7787217.3 & 20139.38 & 30187258.97 & 318677.96 \\
\hline 2015 & 798971.82 & 8548142.7 & 21804.27 & 32682790.48 & 345022.55 \\
\hline 2016 & 838920 & 9347114.5 & 23501.82 & 35227278.89 & 371883.96 \\
\hline 2017 & 880866.36 & 10186035 & 25237.56 & 37828998.18 & 399349.54 \\
\hline 2018 & 0 & 11066901 & 27016.97 & 40496196.15 & 427506.36 \\
\hline 2019 & 0 & 11066901 & 24939.81 & 37382700.63 & 394638.11 \\
\hline 2020 & 0 & 11066901 & 23022.34 & 34508582.03 & 364296.89 \\
\hline Total & & & & 496787641 & 5244440.15 \\
\hline
\end{tabular}

Appendix 2. Estimated Methane and Electricity generation at Abule Egba Landfill

\begin{tabular}{|c|c|c|c|c|c|}
\hline \multirow{2}{*}{ Year } & Waste Accepted & Waste-In-Place & \multicolumn{2}{|c|}{ Methane } & Electricity \\
\cline { 2 - 6 } & $\boldsymbol{M g}$ & $\boldsymbol{M g}$ & $\boldsymbol{M g}$ & $\boldsymbol{m}^{\mathbf{3}}$ & $\boldsymbol{M} \boldsymbol{W h}$ \\
\hline 1995 & 70,000 & 0 & 0 & 0 & 0 \\
\hline 1996 & 74,200 & 70,000 & 295.60 & $443,079.77$ & $4,677.46$ \\
\hline
\end{tabular}




\begin{tabular}{|c|c|c|c|c|c|}
\hline 1997 & 78,652 & 144,200 & 586.21 & $878,678.74$ & $9,275.95$ \\
\hline 1998 & 83,371 & 222,852 & 873.28 & $1,308,967.14$ & $13,818.38$ \\
\hline 1999 & 88,373 & 306,223 & $1,158.20$ & $1,736,043.31$ & $18,326.9$ \\
\hline 2000 & 93,676 & 394,596 & $1,442.34$ & $2,161,945.51$ & $22,823.02$ \\
\hline 2001 & 99,296 & 488,272 & $1,727.03$ & $2,588,669.26$ & $27,327.82$ \\
\hline 2002 & 105,254 & 587,568 & $2,013.56$ & $3,018,157.89$ & $31,861.8$ \\
\hline 2003 & 111,569 & 692,822 & $2,303.22$ & $3,452,338.30$ & $36,445.31$ \\
\hline 2004 & 111,569 & 804,391 & $2,597.28$ & $3,893,109.45$ & $41,098.4$ \\
\hline 2005 & 167,354 & 915,960 & $2,868.73$ & $4,299,992.50$ & $45,393.75$ \\
\hline 2006 & 251,031 & $1,083,314$ & $3,354.89$ & $5,028,695.83$ & $53,086.45$ \\
\hline 2007 & 375,547 & $1,334,345$ & $4,157.02$ & $6,231,025.02$ & $65,779.09$ \\
\hline 2008 & 564,820 & $1,709,892$ & $5,423.29$ & $8,129,065.05$ & $85,816.14$ \\
\hline 2009 & 353,012 & $2,274,712$ & $7,391.48$ & $11,079,220.23$ & $116,960.05$ \\
\hline 2010 & 0 & $2,627,724$ & $8,313.92$ & $12,461,873.26$ & $131,556.31$ \\
\hline 2011 & 0 & $2,627,724$ & $7,674.71$ & $11,503,758.91$ & $121,441.78$ \\
\hline 2012 & 0 & $2,627,724$ & $7,084.65$ & $10,619,307.90$ & $112,104.89$ \\
\hline 2013 & 0 & $2,627,724$ & $6,539.96$ & $9,802,856.71$ & $103,485.86$ \\
\hline 2014 & 0 & $2,627,724$ & $6,037.14$ & $9,049,177.27$ & $95,529.49$ \\
\hline 2015 & 0 & $2,627,724$ & $5,572.99$ & $8,353,443.46$ & $88,184.83$ \\
\hline 2016 & 0 & $2,627,724$ & $5,144.51$ & $7,711,200.20$ & $81,404.86$ \\
\hline 2017 & 0 & $2,627,724$ & $4,748.99$ & $7,118,334.96$ & $75,146.16$ \\
\hline 2018 & 0 & $2,627,724$ & $4,383.87$ & $6,571,051.36$ & $69,368.65$ \\
\hline 2019 & 0 & $2,627,724$ & $4,046.82$ & $6,065,844.92$ & $64,035.33$ \\
\hline 2020 & 0 & $2,627,724$ & $3,735.68$ & $5,599,480.60$ & $59,112.06$ \\
\hline Total & & & & $\mathbf{1 4 9 , 1 0 5 , 3 1 7 . 6 0}$ & $\mathbf{1 , 5 7 4 , 0 6 0 . 7 4}$ \\
\hline & & & & & \\
\hline
\end{tabular}

Appendix 3. Potential Methane and Electricity generation in Solous I Landfill

\begin{tabular}{|c|c|c|c|c|c|}
\hline \multirow{2}{*}{ Year } & Waste Accepted & Waste-In-Place & \multicolumn{2}{|c|}{ Methane } & Electricity \\
\cline { 2 - 6 } & $\boldsymbol{M g}$ & $\boldsymbol{M g}$ & $\boldsymbol{M g}$ & $\boldsymbol{m}^{\mathbf{3}}$ & $\boldsymbol{M W h}$ \\
\hline 1996 & 100,122 & 0 & 0.00 & 0.00 & 0.00 \\
\hline 1997 & 106,512 & 100,122 & 422.80 & $633,743.33$ & $6,690.24$ \\
\hline 1998 & 113,311 & 206,634 & 840.08 & $1,259,209.01$ & $1,3293.1$ \\
\hline 1999 & 120,544 & 319,945 & $1,253.99$ & $1,879,622.31$ & $19,842.62$ \\
\hline 2000 & 128,238 & 440,489 & $1,666.62$ & $2,498,118.77$ & $26,371.9$ \\
\hline 2001 & 136,423 & 568,727 & $2,080.01$ & $3,117,763.76$ & $32,913.31$ \\
\hline 2002 & 145,131 & 705,150 & $2,496.19$ & $3,741,576.86$ & $39,498.72$ \\
\hline 2003 & 154,395 & 850,281 & $2,917.14$ & $4,372,548.06$ & $46,159.7$ \\
\hline 2004 & 164,250 & $1,004,676$ & $3,344.85$ & $5,013,646.33$ & $52,927.58$ \\
\hline 2005 & 264,375 & $1,168,926$ & $3,781.29$ & $5,667,833.92$ & $59,833.65$ \\
\hline 2006 & 184,781 & $1,433,301$ & $4,606.98$ & $6,905,487.50$ & $72,899.19$ \\
\hline 2007 & 0 & $1,618,082$ & $5,033.09$ & $7,544,178.73$ & $79,641.66$ \\
\hline 2008 & 0 & $1,618,082$ & $4,646.12$ & $6,964,154.71$ & $73,518.52$ \\
\hline 2009 & 0 & $1,618,082$ & $4,288.91$ & $6,428,725.05$ & $67,866.15$ \\
\hline 2010 & 0 & $1,618,082$ & $3,959.17$ & $5,934,461.18$ & $62,648.35$ \\
\hline 2011 & 0 & $1,618,082$ & $3,654.77$ & $5,478,198.12$ & $57,831.72$ \\
\hline 2012 & 0 & $1,618,082$ & $3,373.78$ & $5,057,014.24$ & $53,385.4$ \\
\hline 2013 & 0 & $1,618,082$ & $3,114.39$ & $4,668,212.50$ & $49,280.94$ \\
\hline 2014 & 0 & $1,618,082$ & $2,874.94$ & $4,309,303.27$ & $45,492.04$ \\
\hline 2015 & 0 & $1,618,082$ & $2,653.91$ & $3,977,988.29$ & $41,994.45$ \\
\hline 2016 & 0 & $1,618,082$ & $2,449.87$ & $3,672,146.02$ & $38,765.76$ \\
\hline 2017 & 0 & $1,618,082$ & $2,261.51$ & $3,389,818.01$ & $35,785.31$ \\
\hline 2018 & 0 & $1,618,082$ & $2,087.64$ & $3,129,196.42$ & $3,3034.00$ \\
\hline 2019 & 0 & $1,618,082$ & $1,927.13$ & $2,888,612.37$ & $30,494.23$ \\
\hline 2020 & 0 & $1,618,082$ & $1,778.97$ & $2,666,525.29$ & $28,149.72$ \\
\hline Total & & & & $\mathbf{1 0 1 , 1 9 8 , 0 8 4 . 1}$ & $\mathbf{1 0 6 , 8 3 1 8 . 3}$ \\
\hline & & & & & \\
\hline
\end{tabular}


Appendix 4. Projection of future electricity that would be generated from Lagos landfills from 2015-2050

\begin{tabular}{|c|c|c|c|c|c|c|}
\hline \multirow[t]{2}{*}{ Year } & \multirow{2}{*}{$\begin{array}{c}\text { Waste Accepted } \\
M g\end{array}$} & \multirow{2}{*}{$\begin{array}{c}\text { Waste-In-Place } \\
M g\end{array}$} & \multicolumn{2}{|c|}{ Methane } & \multirow{2}{*}{$\begin{array}{c}\text { Electricity Generated } \\
M W h \\
\end{array}$} & \multirow{2}{*}{$\begin{array}{c}\text { Electricity Needs } \\
M W h\end{array}$} \\
\hline & & & $M g$ & $m^{3}$ & & \\
\hline 2015 & 10328783 & 0 & 0 & 0 & 0 & 5173926 \\
\hline 2016 & 10659304 & 10328783 & 43617 & 65378209 & 7286 & 5339491 \\
\hline 2017 & 11000401 & 20988086 & 85276 & 127822006 & 1349379 & 5510355 \\
\hline 2018 & 11352414 & 31988487 & 125173 & 187623944 & 1980690 & 5686686 \\
\hline 2019 & 11715691 & 43340902 & 163489 & 245056232 & 2586986 & 5868660 \\
\hline 2020 & 12090593 & 55056593 & 200393 & 300372354 & 3170942 & 6056457 \\
\hline 2021 & 12477492 & 67147186 & 236043 & 353808593 & 3735053 & 6250264 \\
\hline 2022 & 12876772 & 79624679 & 270586 & 405585418 & 4281645 & 6450272 \\
\hline 2023 & 13288829 & 92501451 & 304159 & 455908777 & 4812894 & 6656681 \\
\hline 2024 & 13714072 & 105790280 & 336891 & 504971292 & 5330833 & 6869695 \\
\hline 2025 & 14169285 & 119504352 & 368902 & 552953365 & 5837365 & 7089525 \\
\hline 2026 & 14605816 & 133673637 & 400374 & 600127773 & 6335371 & 7316390 \\
\hline 2027 & 15073201 & 148279453 & 431270 & 646438350 & 6824258 & 7550514 \\
\hline 2028 & 15555544 & 163352654 & 461765 & 692146816 & 7306789 & 7792131 \\
\hline 2029 & 16053321 & 178908198 & 491951 & 737394139 & 7784452 & 8041479 \\
\hline 2030 & 16567028 & 194961520 & 521919 & 782313469 & 8258652 & 8298806 \\
\hline 2031 & 17097172 & 211528547 & 551752 & 827030849 & 8730720 & 8564368 \\
\hline 2032 & 17644282 & 228625719 & 581531 & 871665857 & 9201919 & 8838428 \\
\hline 2033 & 18208899 & 246270001 & 611330 & 916332208 & 9673448 & 9121258 \\
\hline 2034 & 18791584 & 264478900 & 641222 & 961138311 & 10146453 & 9413138 \\
\hline 2035 & 19392914 & 283270484 & 671277 & 1006187781 & 10622026 & 9714358 \\
\hline 2036 & 20013488 & 302663399 & 701560 & 1051579933 & 11101218 & 10025218 \\
\hline 2037 & 20653919 & 322676887 & 732136 & 1097410220 & 11585035 & 10346025 \\
\hline 2038 & 21314845 & 343330806 & 763065 & 1143770653 & 12074448 & 10677098 \\
\hline 2039 & 21996920 & 364645650 & 794407 & 1190750194 & 12570398 & 11018765 \\
\hline 2040 & 22700821 & 386642570 & 826220 & 1238435114 & 13073793 & 11371365 \\
\hline 2041 & 23427248 & 409343391 & 858560 & 1286909337 & 13585521 & 11735249 \\
\hline 2042 & 24168056 & 432770639 & 891480 & 1336254754 & 14106446 & 12106337 \\
\hline 2043 & 24950581 & 456938695 & 924998 & 1386495417 & 14636822 & 12498322 \\
\hline 2044 & 25748999 & 481889276 & 959244 & 1437826552 & 15178710 & 12898268 \\
\hline 2045 & 26572967 & 507638275 & 994228 & 1490264919 & 15732286 & 13311013 \\
\hline 2046 & 27423302 & 534211242 & 1030002 & 1543887112 & 16298360 & 13736965 \\
\hline 2047 & 28295087 & 561634545 & 1066616 & 1598769011 & 16877732 & 14173662 \\
\hline 2048 & 29206475 & 589929631 & 1104097 & 1654949532 & 17470813 & 14630197 \\
\hline 2049 & 30141083 & 619136107 & 1142545 & 1712579514 & 18079195 & 15098364 \\
\hline 2050 & 31105597 & 649277189 & 1181983 & 1771694488 & 18703255 & 15581511 \\
\hline Total & & & & 32181832493 & 339051195 & 340811242 \\
\hline
\end{tabular}

\section{Copyright Disclaimer}

Copyright for this article is retained by the author(s), with first publication rights granted to the journal.

This is an open-access article distributed under the terms and conditions of the Creative Commons Attribution license (http://creativecommons.org/licenses/by/3.0/). 